\title{
17. GLAUCONITE MINERALOGY OF SITE 246, DEEP SEA DRILLING PROJECT, LEG 25
}

\author{
Stan M. White, California State University, Fresno, California
}

\begin{abstract}
In sediments recovered from Site 246, glauconite occurs as discrete pellets and fossil casts, internal molds, or replacements. The glauconite formation mechanism is attributed to a glauconitization of clay minerals which flocculate into pellets or impregnate shells. Evidence contained in the sediments of Units 2 and 3 support the glauconite-forming environmental conditions reported in the literature.
\end{abstract}

\section{INTRODUCTION}

Sediment samples (Table 1) taken from cores of Site 246 between 0 and 194 meters below the sea floor $(94 \mathrm{~m}$ cored and $23.8 \mathrm{~m}$ recovered) were studied in an effort to determine the overall characteristics of the glauconite component in the sediments. Glauconite most commonly occurs in the sediment (Core 11) that consists primarily of early Eocene shelly-foraminiferal and calcareous sand with associated volcanic sandstone, volcanic breccia, and minor silty clay. However, glauconite was observed in all samples from Core 4 to the base of the drilled sequence.

Twenty-two sediment samples were impregnated with epoxy, and petrographic thin sections were made. The slides were examined to determine overall petrologic characteristics of the glauconitic sediment and to determine specific

TABLE 1

Sediment Samples Studied from Site 246 (Thin Sections)

\begin{tabular}{l|c|c}
\hline & \multicolumn{2}{|c}{ Cored Interval } \\
\hline \multirow{2}{*}{$\begin{array}{l}\text { Core, Section, } \\
\text { Interval (cm) }\end{array}$} & $\begin{array}{l}\text { Depth Below } \\
\text { Sea Floor (m) }\end{array}$ & $\begin{array}{l}\text { Depth Below } \\
\text { Sea Level (m) }\end{array}$ \\
\hline $4-5,24-26$ & $119-124$ & $1054-1163$ \\
4, CC & & \\
5, CC & 137 & $1163-1172$ \\
$8-1,38-40$ & 155 & $1190-1199$ \\
$9-1,138-140$ & & \\
$9-3,133-135$ & & \\
$9-5,139-141$ & $164-173$ & $1199-1208$ \\
$9-6,144-146$ & & \\
9, CC & & \\
$10-1,90-92$ & & \\
$10-1,138-140$ & $176-185$ & \\
$10-2,14-16$ & & \\
$10-2,110-113$ & & \\
$11-1,49-51$ & & \\
$11-1,119-120$ & & \\
$11-2,1-3$ & & \\
$11-2,26-28$ & $185-194$ & \\
$11-2,49-51$ & & \\
$11-2,72-74$ & & \\
$11-2,128-130$ & & \\
$11-2,148-150$ & & \\
11, CC & & \\
\hline
\end{tabular}

mineralogical characteristics of the glauconite. Thin section examinations were supplemented by binocular microscope examinations of these and twenty-six other sediment samples. X-ray, carbon-carbonate, and grain-size data of certain core samples supported the overall study.

\section{PHYSIOGRAPHIC SETTING}

Site 246 , located at lat $33^{\circ} 37.21^{\prime} \mathrm{S}$, long $45^{\circ} 09.60^{\prime} \mathrm{E}$ and in 1030 meters of water, is slightly east of the Madagascar Ridge crest (Figure 1). It is about 60 miles southeast of Walter's Shoals, which is the shallowest part along the ridge at 20 meters below sea level. The ridge is considered to be one of the aseismic ridges of possible continental origin in the Indian Ocean (Laughton et al., 1970). It trends southward from Madagascar, terminating in a bold bluff at $35^{\circ} \mathrm{S}$. The east flank slopes gently down to the southern Madagascar Basin while on the west flank, the ridge bounds the Mozambique Basin with a steep scarp.

\section{STRATIGRAPHY}

Three lithostratigraphic units, ranging in age from Quaternary to early Eocene (Paleocene?), are recognized. Unit 1, 125 meters thick, is a Quaternary to lower Miocene sand-size planktonic foraminiferal ooze with minor nannofossil foraminifera ooze. Detrital silt and bioclastic (upper shelf) debris occur in Core 1, while authigenic pyrite occurs in Cores 2 and 3 . The base of the unit is marked by a pebbly, calcareous volcanic sandstone.

Unit 2 is dominantly an unconsolidated shell-rich to shelly calcareous sand with local glauconite-rich calcareous sand zones. The faunal characteristics are those of a neritic or shallow-water environment with a mixed assemblage of planktonic and shelf benthonic foraminifera. The unit is 51 meters thick and is early Eocene to early middle Miocene in age.

Unit 3,18 meters thick, is primarily an unconsolidated glauconitic, calcareous sand with local shelly/zeolite-rich volcanic sand, and thin $(0-3 \mathrm{~cm})$ layers of lithified volcanic sandstone, breccia, and limestone. Local clay and ash beds are minor. The oldest sediment in the unit is possibly Paleocene in age. 


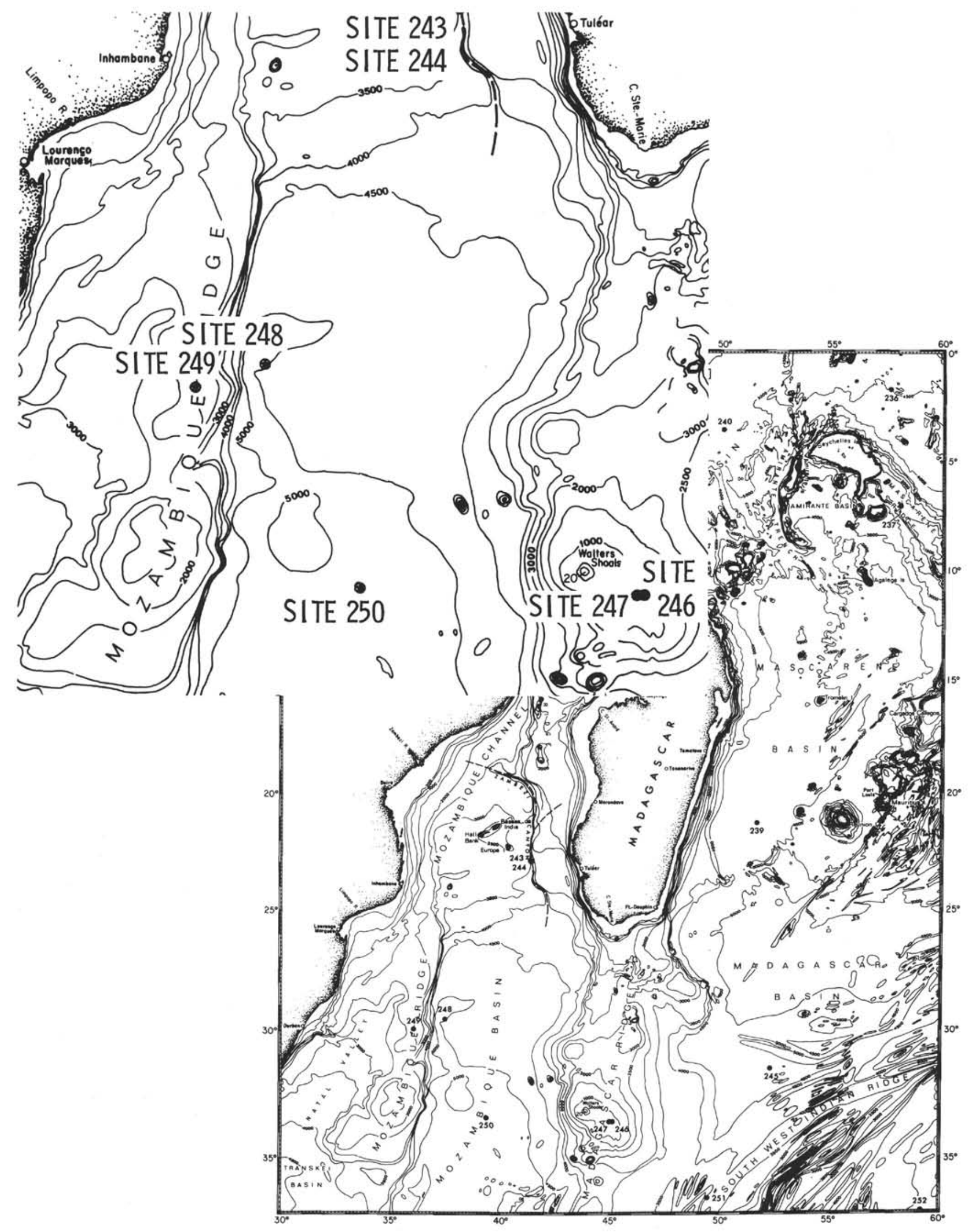

Figure 1. Location map - Site 246. 


\section{SUPPLEMENTAL SEDIMENT ANALYSES}

Samples were taken from Cores 5 and 9 (Unit 2) and 10 and 11 (Unit 3) for X-ray, carbon-carbonate, and grain-size studies. A brief summary of the results follows.

\section{X-ray Analyses}

A total of eight samples were taken for X-ray studies from Cores 5, 9, 10, and 11 .

\section{Bulk}

The calcite content is high (54.0\% to $91.8 \%$ ) as would be expected in cores of shelly-calcareous sand (Cores 5, 9, and 11). The quartz content ranges from 0 to 2.7 percent, while the potassium feldspar content ranges from 8.2 to 54.4 percent. Lowest values for the feldspar are in two samples of Core 9 and one sample of Core 11. Two samples from Core 10 contain montmorillonite $(3.2 \%$ and $3.6 \%)$ and phillipsite (10.5\% and $11.8 \%$ ).

\section{2 to 20 Micron Fraction}

Higher values of quartz $(2.3 \%-13.3 \%)$ and potassium feldspar $(51.6 \%-92.5 \%)$ occur in this size fraction. The abundances of the two minerals parallel one another except in two samples. Montmorillonite was reported in the four samples of Cores 10 and 11 with values of 3.5 to 9.3 percent; clinoptilolite had values of 1.5 to 3.8 percent in three samples (Cores 9 and 10); and phillipsite had values of 25.8 to 35.1 percent in two samples of Core 10. Pyrite occurs in one sample of Core $11(7.2 \%)$ while goethite is reported as being present $(5 \%-25 \%)$ in the two samples of Core 11. Three samples (Cores 5, 9, and 11) have a mixed-layer clay (with a broad peak at $11 \AA$ and $10.5 \AA$ ). Values reported for this clay ranged from 3.1 percent (Core 5) to 14.6 percent (Core 11)

\section{Less than 2 Micron Fraction}

The data shows: montmorillonite (17.0\%-67.1\%) in four samples from Cores 10 and 11; clinoptilolite in one sample (2.1\% in Core 10$)$; phillipsite $(25.3 \%-39.3 \%)$ in two samples of Core 10; mixed-layer clays $(20.4 \%-100.0 \%)$ in every sample except the two samples of Core 10; and goethite is present $(5 \%-25 \%)$ in Core 5 , with trace (less than $5 \%$ ) amounts in Core 9, and abundant amounts (25\%-65\%) in one sample of Core 11.

\section{Carbon-Carbonate Analyses}

Four samples were taken from Cores 5, 9, and 11 for carbon-carbonate studies. The percentages reported for total carbon, organic carbon, and calcium carbonate are: Core $5(6.2 \%, 0.1 \%$, and $51.0 \%)$; Core 9 , Section $2(9.3 \%$, $0.1 \%$, and $77.0 \%$ ); Core 9 , Section $6(9.8 \%, 0.0 \%$, and $81.0 \%)$; and Core $11(8.1 \%, 0.1 \%$, and $67.0 \%)$.

\section{Grain-Size Analyses}

Fifteen grain-size samples were taken from three cores $(5,9$, and 11). Eight of the samples are sand and seven are silty sand. The sand percentages within the samples range from a high of 93.7 (Core 11, Section 2) to a low of 64.6 (Core 9, Section 6), with an average of 79.4. Silt averages 12.3 percent and clay averages 8.3 percent.

\section{MICROSCOPIC STUDIES}

Twenty-six samples, in addition to the twenty-two used petrographic thin section studies, were examined to determine characteristics of the glauconite.

\section{Binocular Microscope Studies}

\section{Procedure}

Binocular slides were made from both washed and unwashed samples (Table 2). The washing technique involved boiling the sample in water and/or a warm-water ultrasonic treatment. Dilute $\mathrm{NaOH}$ was added as needed to deflocculate the clays. The samples were wet sieved through 50 and 100 mesh screens, residues were dried, and then slides were made of the residues.

TABLE 2

Binocular Microscope Studies

\begin{tabular}{ll}
\hline \multicolumn{2}{c}{ Samples Used In Study } \\
\hline $9-1,49-51 \mathrm{~cm}$ & $9-6,29-31 \mathrm{~cm}$ \\
$9-1,99-101 \mathrm{~cm}$ & $9-6,84-86 \mathrm{~cm}$ \\
$9-1,119-121 \mathrm{~cm}$ & $10-1,134-136 \mathrm{~cm}$ \\
$9-2,30-32 \mathrm{~cm}$ & $10-1,148-150 \mathrm{~cm}$ \\
$9-2,79-81 \mathrm{~cm}$ & $10-2,18-20 \mathrm{~cm}$ \\
$9-2,140-142 \mathrm{~cm}$ & $10-2,75-77 \mathrm{~cm}$ \\
$9-3,24-26 \mathrm{~cm}$ & $10-2,80-82 \mathrm{~cm}$ \\
$9-3,72-74 \mathrm{~cm}$ & $10-2,88-90 \mathrm{~cm}$ \\
$9-3,149-150 \mathrm{~cm}$ & $11-1,87-89 \mathrm{~cm}$ \\
$9-4,29-31 \mathrm{~cm}$ & $11-2,19-21 \mathrm{~cm}$ \\
$9-4,74-76 \mathrm{~cm}$. & $11-2,59-61 \mathrm{~cm}$ \\
$9-4,145-147 \mathrm{~cm}$ & $11-2,137-139 \mathrm{~cm}$ \\
$9-5,70-72 \mathrm{~cm}$ & $11, C \mathrm{C}$ \\
\hline
\end{tabular}

\section{Paleontology}

Unit 3 can be characterized as a shallow warm-water assemblage, possibly even reef influenced, which may have been transported into a deeper, open-shelf environment before final deposition. Transportation is suspected because of the presence of a small, but constant, fraction of fairly fresh and unaltered planktonic and open-shelf foraminifera (e.g., Cibicides, Discorbis, Gyroidina, Globigerina, and Globorotalia) within the main body of shallow-water bioclastic debris. Also occurring are echinoid plates and spines, pelecypod and brachiopod fragments, bryozoans, and shallow-water foraminifera (e.g., Discocyclina, Asterocyclina, Textularia, Nodosaria, Lenticulina, Astacolis, and Nummulites). Discocyclina and Asterocyclina are the most abundant identifiable fossils in Unit 3. In some parts of Core 11 , they may constitute up to 50 percent of the total sediment. These genera are usually more or less heavily abraded and infilled with glauconite.

Above Core 11, Discocyclina (Asterocyclina) decline drastically in number but are still found up to the top of Core 5, although they may be reworked from older sediments. The tests of these genera are frequently very heavily stained with ferric oxide and/or are filled with glauconite. The proloculus and equatorial layer are almost inevitably filled with glauconite, even though the surface of the test may appear very fresh (Figure 2B).

Nummulites has about the same occurrence habits as Discocyclina, but never is as abundant. Specimens are 


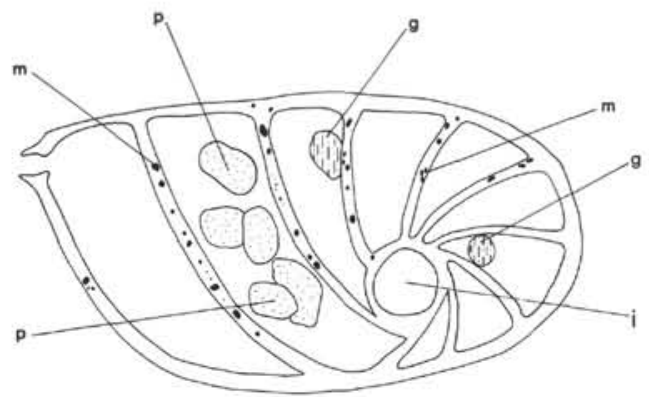

axo $25-246-11-2-19-21$ $1 \mathrm{~mm}$
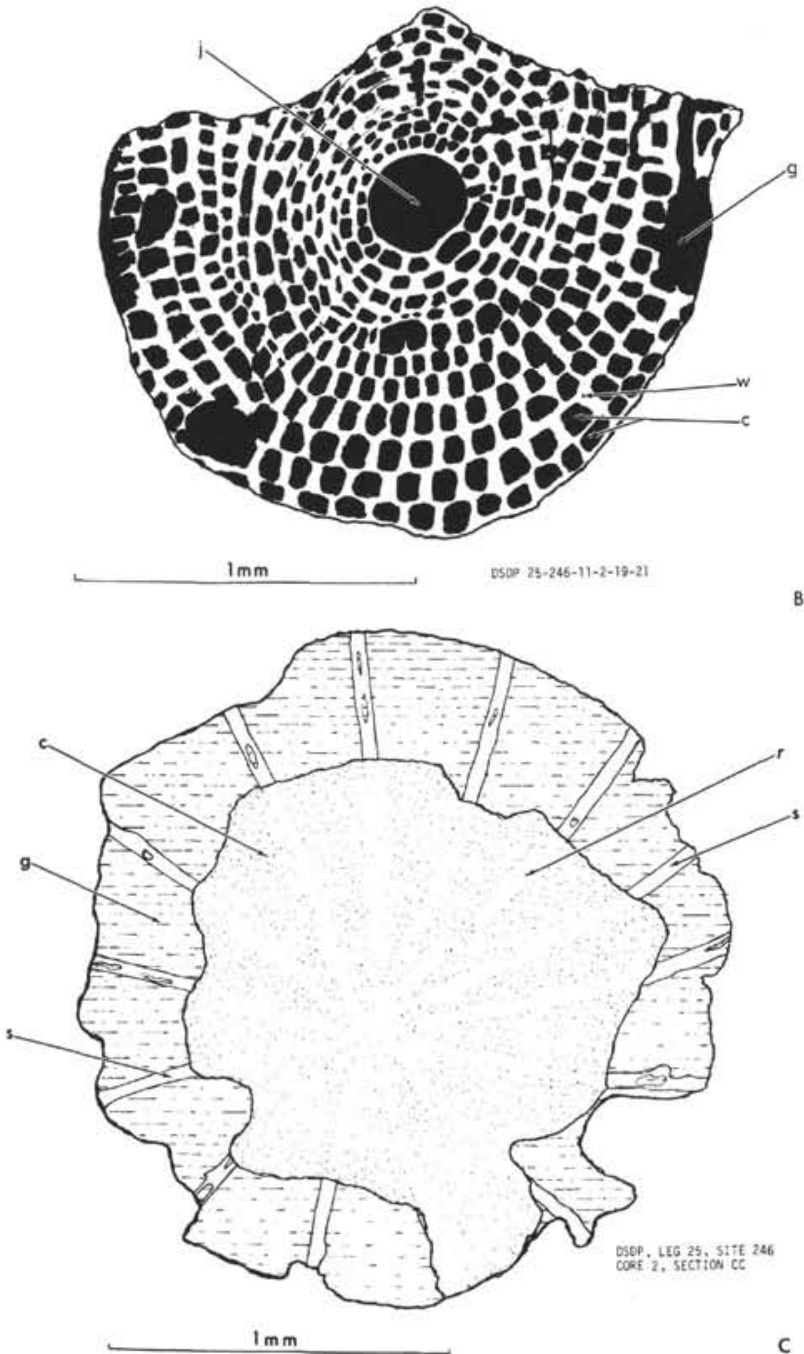

Figure 2. Various occurrences of glauconite in the sediments of Site 246. (a) Cross-sectional cut of Astacolis showing isolated glauconite pellets ( $g$ ) within chambers; clear calcite (?) lumps ( $p$ ) within chambers and magnetite (?) $(\mathrm{m})$ in shell walls. The juvenile portion or proloculus is indicated; (j) (b) Equatorial section of Discocylina showing total glauconitization (g) of infillings in juvenile proloculus ( $j$ ) and other chambers (c). The larger areas of glauconite ( $g$ ) are believed to be the result of enlargement of the glauconite in the chambers obliterating the calcitic internal structure $(w)$ which is stained green. (c) Side view of a glauconite cast, possibly of Lenticulina. The orange-stained remains of the calcite test are the stippled area (c) and shows faint traces of sutures ( $r)$. This remnant partly covers the glauconite-filled chambers $(\mathrm{g})$. The specimen has been so completely eroded on the edges that the only remaining parts of the test are the sutures (s).

usually quite small and very abraded. Chambers are almost always filled with glauconite and often the only sign of Nummulites is an internal cast of glauconite with residual sutures and a bit of stained and weathered test.

Large Lenticulina and Astacolis are found in Unit 3 and in younger cores. In several places in Core 11, these genera rival the large rotalids in size and number. The Lagenids are often well preserved but more commonly are heavily abraded. Glauconite usually occurs as small, rounded pellets in the chambers of these genera (Figure 2A and 2C). Complete infilling of the chambers, however, occurs in some cases (Figure 2C).

Unit 2 is quite similar to Unit 3 , both faunally and lithologically. The main difference is a decrease in the amount of glauconite and in the number of individuals of the large shallow-water forams mentioned above in Unit 3. Echinoid remains are the dominant bioclastic sediment in the basal and middle parts of Unit 2, with planktonic forams being very scarce at the bottom, but becoming dominant at the top. Lenticulina and Astacolis have a sporadic, but sometimes abundant, occurrence throughout Unit 2 while the large rotalids decline steadily in number up to the top of the unit. Abrasion of the sediment is considerably less, and the presence of extremely well preserved whole juvenile echinoderms and Pecten spats (?) suggests that the sediment was not transported far downslope. This is also supported by the more weathered look of the planktonic and open-shelf types, suggesting that they were transported into shallow water rather than into deeper water.

Unit 1 represent a very considerable faunal and lithological departure from the essentially shallow-water deposits of Units 2 and 3 . The bottom core of Unit 1, Core 4 , is a mixture of shallow-water and planktonic foraminifera as well as bryozoans, shell fragments, and echinoid remains; this indicates that conditions probably were open shallow water at this time in the Miocene. Deepening, and isolation from shallow-water sediment influences, is indicated in the lower Pliocene (Core 2) by a foram assemblage of a highly characteristic planktonic and deep-water benthonic nature. A few glauconitized casts of Discocyclina and Lenticulina are seen in Unit 1, but these are almost certainly reworked or the results of drilling contamination. Glauconite is not abundant, even at the base of Unit 1; it never exceeds 2 percent. None of the forams of Unit 1 are glauconitized although orange iron oxide staining is quite common. Genera seen in Unit 1 are: Textularia, Globigerina, Globoquadrina, Lagena, and Globigerina, as well as all of the genera mentioned previously.

\section{Glauconite and Associated Mineralogy}

Glauconite occurs in all samples from Core 2 to Core 11 with the concentrations increasing with increasing depth. 
The glauconite occurs as: (1) discrete grains ("pellets") ranging in color from a "grass" (pale) green to dark green, olive green, and greenish brown (red brown); and (2) glauconite staining of fossils, replacement of fossils, and as in infilling in zooecia of bryozoa and in the chambers of Nummulites and Discocylina. All of these occurrences are more prevalent in Core 11 than in any other core. Minerals include: quartz (which increases in roundness with increasing depth); abraded and worn fossil fragments and calcium carbonate fragments; lithic fragments (predominantly volcanic); and magnetite. The magnetite, with percentages of up to 8 percent, was ubiquitious throughout all the cores.

\section{Thin Section Studies}

Twenty thin sections were made from the sediment samples (Table 1). The samples were first mounted in epoxy and thin sections made using standard procedures.

In Cores $4-8$, the samples are a foraminifera-bearing, shell-rich calcareous sand. Quartz and feldspar average 3 percent and, for the most part, are angular grains. Lithic fragments (1\%-2\%) are volcanics. Glauconite occurs as brownish-red, brown rimmed ovoid grains with "septarialike" fracturing. The interior of the grains is pale green to dusky green. In some cases, portions of shells or tests incorporate an irregularly shaped glauconite mass.

Core 9 is lithologically similar to Cores $4-8$ except that it is glauconite-bearing and shows more carbonate recrystallization. Quartz and feldspar (3\%) are angular, and lithic fragments are volcanic.

The glauconite has the following occurrences: (1) local, irregular to ovoid growth centers, pale green in color, and scattered throughout the sediment; (2) replacement of, or perhaps a coating on, shell fragments; (3) irregular masses partially surrounded by a calcareous shell or test fragment; (4) ovoid grains surrounding a reddish-brown core; and (5) discrete ovoid pellets with light to heavy exterior brown staining. The deeper samples of Core 9 (Section 6 and CC) show a large increase in the presence of the reddish-orange to reddish-brown staining. The staining affects all components of the sediment.

Core 10 is a glauconite-bearing, shell-rich calcareous sand. Quartz and feldspar (5\%-7\%) show a tendency to be subangular to subrounded. Volcanic lithic fragments (1\%) and carbonate fragments also have rounded outlines. Glauconite occurs as: reddish-brown pellets with "septaria" fracturing; pale to dusky green pellets with and without "septaria" fracturing (some have reddish-brown rims and ovoid shapes); and as chamber infillings in foraminifera.

Core 11 distinguishes itself by being a glauconite-rich calcareous sand. Quartz and feldspar have a higher percentage (3\%-13\%) than the shallower samples and exhibit shapes from subangular to well rounded. The volcanic lithic fragments and carbonate fragments also show a high degree of rounding. Glauconite abundances exceed 10 percent with a maximum of 25 percent. The varied occurrences of glauconite show that the isolated ovoid glauconite pellets are most common; some have excellent "septaria" fracturing. Glauconite was also noted as: shell or test infillings; replacements or coatings of volcanic lithics; partial to total shell or test replacement; and as an admixture with carbonate around quartz grains.

\section{Microscopic Summary}

\section{Color Classification}

The binocular and thin section studies allow a possible four-fold classification of the glauconite based on color:

1) A pale green ( $5 G 7 / 2$ ), often transparent to translucent, to moderate yellow green (5GY 7/4). Glauconite of this variety can be characterized morphologically as looking like "green glass". It occurs as "septaria-like" infillings in pellet fractures, as a replacement of fossil skeletons, as ovoid-nodular isolated grains, and within chambers of foraminifera. The yellow-green color is altered in part by the red- to reddish-yellow to reddish-brown iron oxide stain.

2) A dusky opaque green (5G 3/2). This variety also occurs as discrete grains or nodular masses with "septaria-like" fractures. The masses are very smooth and have well-rounded shapes. They appear very durable and will split rather than fragment into small pieces. Often the "septaria-like" fractures are infilled with pale green (5G $7 / 2$ ) glauconite. Varying intensities of reddish-brown or red-yellow iron oxide staining lead to darker brown (brownish black) varieties

3) A moderate reddish-orange (1OR 6/6) to moderate reddish-brown (1OR 4/6) variety. This variety is believed to be an iron oxide stained or iron oxide replacement variety of those already cited. It appears that the staining is a diagenetic (post-glauconite) phenomena. This staining commonly occurs on associated fauna in the sediment.

4) A fourth variety represents admixtures of those cited above. This variety, however, is not overly common. Single pellets are noted with a dusky green core and a pale green outer layer. Other fragmented grains illustrate a "banding" of these two varieties. Some pale green varieties have a moderate reddish-orange to reddish-brown rind or rim. This is also true for the dusky green grains.

\section{Morphology}

Triplehorn (1966) described and established seven morphological categories for glauconite grains. The samples of Site 246 show these seven varieties. It is instructive in this report, however, to establish only two basic morphological groups:

1) Discrete pellets (ovoidal or spheroidal, tabular or discoidal, mammilated, ellipsoidal, and composite). These pellets are generally smooth and dusky green and often have a dark (brown) rim. If mammillated or aggregated, the sutures ("septaria-like" fractures) are filled with pale green glauconite or material stained with red or reddish brown iron oxide. In all cases, except in the composite varieties, the pellets show good to excellent roundness. The composite pellets are usually composed of pale green glauconite with isolated dusky green rounded pellets scattered within. Small discrete pellets also occur inside foram chambers (Figure 2A).

2) Fossil casts, internal molds, or replacements. Glauconite almost always infills the proloculus and equatorial chambers of Discocyclina (Asterocyclina) (Figure $2 \mathrm{~B}$ ) with the lateral chambers often infilled also. Glauconite casts are particularly noticeable also in Nummulites, Lenticulina, and byozoans. In Nummulites and Discocyclina (Asterocyclina), the calcareous skeletal 
material is stained or partly replaced by glauconite, and the destruction of the skeletal structure by glauconite growth is observed (Figure 2B).

\section{Internal Structure}

The internal structure for the glauconite in these samples is described as random microcrystalline (Triplehorn, 1966). The structure is an aggregate of micaceous plates with green, greenish-yellow colors and reddish-yellow or reddish-brown staining.

\section{Development of the Glauconite}

The glauconite in the samples of Site 246 is attributable to a "glauconitization" process. The "glauconitization" of a host material involves alteration or replacement of the material. The host material includes: fossil shells, tests, or debris; clay minerals in the sediment sequence or within fossil forms; and possibly fecal matter. There is a general agreement that the glauconite-forming environmental conditions are: normal marine waters; sediments with access to the normal marine waters; a low-sediment influx or a decelerated sedimentation rate; a depth range of 30 to 700 meters, with a preferred depth of 250 meters in tropical waters; and a $\mathrm{pH}$ of 7.8 to 8.0 with an $\mathrm{Eh}$ of 0 to $-100 \mathrm{mv}$ (i.e., slightly reducing). The sediments in Unit 2 (Core 4) and Unit 3 give evidence of these environmental conditions. A profound (30 million year) hiatus in Core 4 and the general absence of glauconite in Cores 1 through 4 , indicates a deeper (1000 meters) environment than that of Cores 5 through 11 .

\section{CONCLUSIONS}

Although many morphologies and colors exist for the glauconite in these samples, the prime mechanism for glauconite formation here is similar to the process reported by Ehlmann et al. (1963). Their ideas are summarized below.

Following the death of marine organisms, colloidal clays will flocculate or detrital clay will impregnate the shells, forming internal molds. The glauconitization process transforms this clay into "glauconite" which is, in most cases, the pale green to moderate yellow-green variety. Ehlman et al. (1963) characterize this glauconite as being potassium-deficient and having an $\mathrm{Fe}_{2} \mathrm{O}_{3}$ content of about 20 percent.

If the shell does not disintegrate, freeing the "pellet", the glauconitization process continues to act on the shell and finally replaces it (Figure 2B, 2C). If the shell does disintegrate, the "pellet" is freed and undergoes a further glauconitization which increases the fixation of potassium and the oxidation of the iron in the glauconite. The pellet then becomes a dusky opaque-green with varying degrees of red to reddish-brown stains. Slight agitation in the environment allows development of mammilated or aggregated "pellets" from the discrete pellet forms. Large single pellets may have "septaria-like" fractures which probably are caused by "dessication cracking" during potassium fixation (Ehlman, et al., 1963). However, the "fractures" in aggregated pellets are most likely iron-stained boundaries between individual pellets.

Other glauconite occurrences in the sediment result from either the glauconitization of already "pelletized" fecal matter or the glauconitization of colloidal clay material which may coat shells, mineral grains, or lithic fragments.

\section{REFERENCES}

Ehlman, A. J., Hulings, N. C., and Glover, E. D., 1963. Stages of glauconite genesis in modern foraminiferal sediments: J. Sediment. Petrol., v. 33, no. 1, p. 87-96.

Laughton, A. S., Matthews, D. H., and Fisher, R. L., 1970. The structure of the Indian Ocean. In The Sea, Maxwell, A. E. (Ed.): New York (Interscience), v. 4, pt. 2, p. 543-586.

Triplehorn, D. M., 1966. Morphology, internal structure and origin of glauconite pellets: Sedimentology, v. 6, p. 247-266. 